\title{
Oxidative Stress and Antioxidant Parameters in Earthworm (Esiena fetida andrei); a Probable index of Environmental Pollution Status
}

\author{
ASAGBA, SO; *ICHIPI-IFUKOR, PC; OKWUDIBIE, C \\ Department of Biochemistry, Faculty of Science, Delta State University, Abraka, Nigeria. \\ *Corresponding Author: Email: patychykyresearch@hotmail.com; patychykyscholar@gmail.com
} Tel: +2347038268448

\begin{abstract}
Oxidative stress and antioxidant responses in earthworms were investigated for use as an index for environmental pollution. The study was done in three test locations (Refinery road, Okere market and PTI roundabout) in Warri an industrial city in Nigeria and Abraka a less industrial city as control. Levels of five stress and antioxidant parameters; lipid peroxidation (LPO), aldehyde oxidase (AO), superoxide dismutase (SOD) catalase (CAT) and ascorbic acid (Vit. C.) were used. There was observed significant $(\mathrm{p}<0.05)$ rise in LPO $(5.83 \pm 0.456$, $5.83 \pm 0.456,4.04 \pm 0.58,4.25 \pm 0.475,2.09 \pm 0.425)$, oxidative enzyme (AO) levels $(0.011 \pm 0.00012,0.008 \pm 0.0021$, $0.0058 \pm 0.0013,0.0022 \pm 0.00009)$ and increase in activities and levels of the antioxidants (SOD: 24.0 3.80 , $12.0 \pm 3.80,16.0 \pm 4.62,5.6 \pm 2.8$; CAT: $0.98 \pm 0.013,1.08 \pm 0.061,0.95 \pm 0.018,0.93 \pm 0.0125$ and Vit. C: $0.175 \pm 0.0172$, $0.118 \pm 0.0148,0.109 \pm 0.014,0.072 \pm 0.004)$ respectively in all study locations in Warri compared to Abraka. These changes were significantly higher in refinery road compared to other locations (Okere market and PTI) in Warri. There were also significant $(\mathrm{p}<0.05)$ negative relationship between LPO and SOD activities $(\mathrm{r}=-0.677)$, AO and $\mathrm{CAT}(\mathrm{r}=-0.718)$ as well as $\mathrm{AO}$ and $\operatorname{SOD}(\mathrm{r}=0.661)$ activities respectively only in the refinery road area while no significant change $(\mathrm{p}>0.05)$ were reported in other locations. The combined data showed significant negative relationship $(\mathrm{p}<0.01)$ between LPO and $\mathrm{AO}(\mathrm{r}=-0.719)$ and a significant positive relationship $(\mathrm{p}<0.01)$ between LPO and (SOD r=0.710, Vit $\mathrm{C} \mathrm{r}=.884)$. It further showed significant $(\mathrm{p}<0.01)$ negative relationship between AO and CAT $(\mathrm{r}=-0.486)$, SOD and Vit $\mathrm{C}(\mathrm{r}=-.648)$, and significant $(\mathrm{p}<0.01)$ positive relationship between Vitamin $\mathrm{C}$ and (SOD $\mathrm{r}=-0.865$, CAT $\mathrm{r}=0.785$ ). It was concluded that rise in levels of the studied antioxidants and LPO in earthworms found in Warri compared to Abraka may have occurred in response to industrial pollution, thus may be used for environmental monitoring.
\end{abstract}

DOI: https://dx.doi.org/10.4314/jasem.v24i8.11

Copyright: Copyright (C) 2020 Asagba et al. This is an open access article distributed under the Creative Commons Attribution License (CCL), which permits unrestricted use, distribution, and reproduction in any medium, provided the original work is properly cited.

Keywords: Environment, Pollution, Oxidative Stress, Antioxidants and Earthworm

Contaminating the environment comprises of any form of initiating or introducing by man any substance capable of causing hazard to the environment, human health or alteration of natural ecosystems which often time contributes to impinging the proper use of the environment (Osioma and Hamilton-Amachree, 2019). Although pollution is considerably costly, it is an inevitable and necessary part of human existence. There is no doubt that the day to day human activity continually contributes to several incidences of environmental pollution. This ranges from activities linked to food search, disposal of wastes or acts of mineral exploration and exploitation (Ogamba et al., 2016; Dawood et al., 2017). The discovery of oil and siting of the Warri Petrochemical Company necessitated the influx of several industries to Warri City in Delta State, Nigeria (Babatola and Uriri, 2013; Akpoborie et al., 2015). This also influenced relocation of people in search of green pastures which eventually led to a rise in the pollution potential in the coastal city. It has been reported that population increase is an established index that contributes to stress on economic resources and undue competition for land and space which also is a disposing factor to environmental pollution (Sherbinin et al., 2007; Ghanem, 2018). Thus as more waste are generated the challenge for easy management of municipal waste is often created (Ogwuleka, 2009; Dimpal, 2012; Duran and Messina, 2019). The environment of Warri as it currently stands has been increasingly reported to be highly stressed by varying levels of anthropogenic and natural activities (Aremu et al., 2002; Obafemi et al., 2012; Igiri et al., 2018). This stress has also been widely reported to reflect in different measures of ecosystem health evidenced in both geophysical, hydrological and biochemical indicators in Warri environments (Egborge 1994; Arimoro et al 2008, Nduka and Orisakwe, 2009; Olalekan and Gordon 2011, Ohimain, 2012, Edegbene and Arimoro, 2012, Ocheri et al., 2014). Giving special emphasis to the study of Egboh (2000), heavy metal concentrations in sediments from major roads and gutters in Warri has been reported to be in an alarming rate compared to that in sub-surface soils in Abraka environs a less

*Corresponding Author: Email: patychykyresearch@hotmail.com; patychykyscholar@gmail.com Tel: +2347038268448 
industrial town as reported by Adaikpo et al. (2005). This study is an indication that one of the causes of pollution in the soils and water bodies in Warri City could be linked to the presence of high concentration of heavy metals. The significance of earthworms in determining ecosystem stability is an open truth owing to their role in the chemical and physical modification of organic matter and their ability to mediate soil porosity (Oni and Hassan 2013). Their ability to influence other invertebrates and microorganisms have earned them a persistent recognition as ecosystem engineers and could be used as key indicators of soil health and monitors of ecosystem toxicity assessment (Spurgeon et al., 2003; Vandecasteele et al 2004; Demuynck et al., 2006; Nahmani et al., 2007a; 2007b; Igiri et al., 2015; Osioma and Hamilton-Amachree 2019). It is an established fact that many contaminants are oxidative stress inducers in many biological species thus could be injurious to man if not properly managed. The measurement of oxidative stress status and antioxidant defense responses in terrestrial animals is an established trend for monitoring perceived threat of pollutants to humans and the environment (Achuba et al., 2005; Achuba, 2008; Oni and Hassan 2013; Ojo et al., 2016; Otmani Del Barrio et al 2018 Osioma and Hamilton-Amachere, 2019). The oxidative enzymes are also established cytosolic enzymes with a core function of xenobiotic metabolism. For example, aldehyde oxidase is responsible for the breakdown of aldehydes and certain nitrogenous compounds that arises from the oxidation of several compounds (Isamah and Asagba 2004; Asagba 2010; Ichipi-Ifukor et al., 2019). Aldehyde oxidase like other oxidative enzymes
(Xanthine, monoamine and sulphite) oxidases are well endowed with molybdenum and the haem which aids them in their ability to reduce sulfoxides and several other aromatic compounds arising from the 1, 2, benzisoxasole derivatives (Kardam and Iyer 1998; Ezedom and Asagba, 2010). Knowing that the biotransformation process in most organisms are primarily targeted at the conversion of injurious foreign compounds to lesser injurious ones, monitoring their trend of activities alongside other antioxidant markers and stress indices like the lipid peroxidation (LPO) in earthworm is a justification for their use as indices of environmental pollution status of Warri, Delta State, Nigeria.

\section{MATERIALS AND METHODS}

Collection of Earthworm Samples: Forty samples of earthworm's (Esiena fetida Andrei) were used for this study. Thirty of the earthworm samples were randomly collected from three locations (A: Refinery Road Area, B: Okere Market Area, C: PTI Roundabout area) in the city of Warri which served as the study/test area as shown in Fig. 1 below while samples which were collected from the open field opposite the Faculty of Science Delta State University, Abraka, Nigeria served as the control. The earthworms were collected with the aid of a spade and forcep from the study locations and transferred into clean containers free from any form of chemicals and was quickly transferred to the laboratory in damp filter papers. All the earthworms used for the study were all adults and were properly developed.

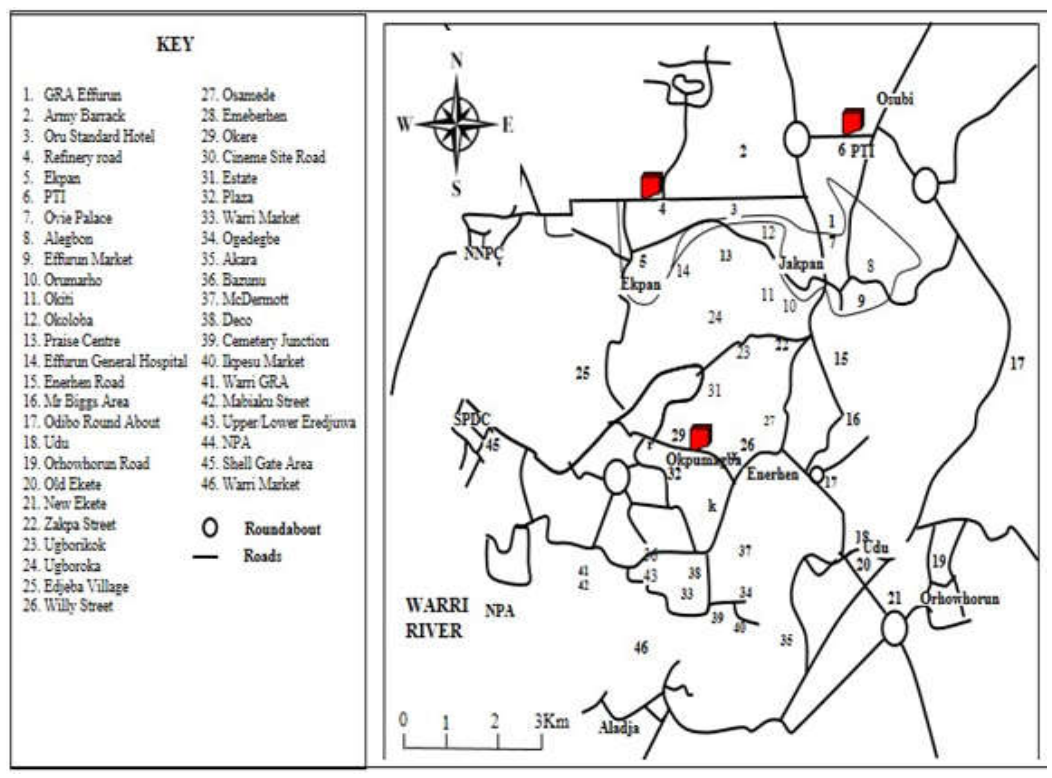

Fig. 1: Map of Warri showing study location

ASAGBA, SO; ICHIPI-IFUKOR, PC; OKWUDIBIE, C 
Chemicals and Reagents: All chemicals and reagents used for the present study were of analytical grade and were purchased from May and Baker Ltd. England and BDH chemicals, Poole England

Preparation of Earthworm Samples: The earthworm from each study location were mechanically homogenized in phosphate buffer $\mathrm{pH} 7.8$ in a 1:4 w/v ratio under chilled conditions. The chilled homogenates were centrifuged at $5,000 \mathrm{~g}$ for $15 \mathrm{mins}$. The supernatant obtained were immediately used for biochemical analysis.

Biochemical Analysis: The lipid hydroperoxide was assayed using the iodometric assay method of Hall and Mair (1978) with little modification by Hall and Braughler (1989). Antioxidant responses were assessed using the activities of two enzymatic antioxidants superoxide dismutase (SOD) and catalase (CAT) and levels of a non-enzymatic antioxidant ascorbic acid (Vit $\mathrm{C}$ ) in the earthworm. SOD was analyzed using the methods of Misra and Fridovich (1972) while the method of Cohen et al., (1970) was used to assay for catalase. The analysis of levels of ascorbic acid (Vit C) was done using method of Plumber (1978). Aldehyde oxidase activity was carried out employing the method of Johns (1967) which was based on decrease in absorbance as a result of oxidation of benzylaldehyde to benzoate in the presence of 2, 6-dichlorophenol-Indophenol (DCIP) as an electron acceptor.
Data Analysis: Data analysis was carried out using the statistical package of the social sciences (SPSS) for analysis of variance (ANOVA) and presented in Mean $\pm \mathrm{SD}$ values. Group comparison was carried out using the least significant difference test. The Pearson correlation was used to test the relationship between parameters in study locations.

\section{RESULTS AND DISCUSSION}

The levels of lipid peroxidation, aldehyde oxidase, superoxide dismutase, catalase and vitamin $\mathrm{C}$ in earthworms are presented in Table 1. The result showed that lipid peroxidation levels of earthworm samples collected from Warri study locations was significantly higher relative to samples collected from the control site (Abraka) $(\mathrm{P}<0.01)$. However, statistical analysis showed that while there was no significant difference in the level of lipid peroxidation in earthworms collected from Okere Market and PTI roundabout areas, there was significant reduction compared to those collected form refinery road area. The study revealed that earthworms from refinery road area are subjected to more oxidative stress than those from other study areas. Pollution has been shown to lead to the generation of environmental contaminants, which as xenobiotic may be harmful to living organisms (Mathew, 2004). Exposure to xenobiotic can greatly induce production of different reactive oxygen species in living organisms enough to generate significant oxidative damage (Timbrell, 1991; Sharma et al., 2012; Klotz and Steinbrenne, 2017).

\begin{tabular}{|c|c|c|c|c|}
\hline \multirow[t]{2}{*}{ Parameter } & \multicolumn{4}{|l|}{ Study Location } \\
\hline & A & B & $\mathrm{C}$ & $\mathrm{D}$ \\
\hline LPO $\left(\mu\right.$ mole $\left.\mathrm{ml}^{-1}\right)$ & $5.83 \pm 0.456^{\mathrm{a}}$ & $4.04 \pm 0.58^{\mathrm{b}}$ & $4.25 \pm 0.475^{\mathrm{b}}$ & $2.09 \pm 0.425^{\mathrm{c}}$ \\
\hline $\operatorname{AO}\left(\mu\right.$ mole $\left.\mathrm{ml}^{-1}\right)$ & $0.011 \pm 0.00012^{\mathrm{a}}$ & $0.008 \pm 0.0021^{\mathrm{b}}$ & $0.0058 \pm 0.0013^{\mathrm{c}}$ & $0.0022 \pm 0.00009^{\mathrm{d}}$ \\
\hline SOD(Unit $\mathrm{g}^{-1}$ tissue) & $24.0 \pm 3.80^{\mathrm{a}}$ & $12.0 \pm 3.80^{\mathrm{b}}$ & $16.0 \pm 4.62^{\mathrm{c}}$ & $5.6 \pm 2.8^{\mathrm{d}}$ \\
\hline $\mathrm{CAT}\left(\mathrm{K} \mathrm{min}^{-1}\right)$ & $0.98 \pm 0.013^{\mathrm{a}}$ & $1.08 \pm 0.061^{\mathrm{b}}$ & $0.95 \pm 0.018^{\mathrm{ac}}$ & $0.93 \pm 0.0125^{\mathrm{d}}$ \\
\hline Vit. C (mg ml $\left.{ }^{-1}\right)$ & $0.175 \pm 0.0172^{\mathrm{a}}$ & $0.118 \pm 0.0148^{\mathrm{b}}$ & $0.109 \pm 0.014^{\mathrm{b}}$ & $0.072 \pm 0.004^{\mathrm{c}}$ \\
\hline
\end{tabular}

Earthworms from refinery road had the highest activities of aldehyde oxidase followed by the Okere market and P.TI roundabout area while Abraka had the least. The differences in the activity of aldehyde oxidase in the earthworms from the various study areas were significant $(p<0.01)$ with respect to each other. SOD enzyme activity were in the order of refinery road area $>$ PTI round about area $>$ Okere market area $>$ Abraka. The SOD activity in the study locations in Warri environment were significantly higher $(p<0.01)$ than that of Abraka. In the Warri study areas, the SOD activity of the earthworms in PTI roundabout was significantly lower than that of refinery road area, but higher than that of earthworms in Okere market area. The degree of SOD activity observed in the study areas of Warri relative to Abraka could be an adaptation to the accompanying stress of pollution in the Warri environments. SOD is an inducible enzyme and its activity will increase with increasing need to protect the organism from oxidative stress or damage (Fridovich, 1986; Achuba, 2018; 2019). During exposure to environmental pollutants and effluents arising from pollution, there is a relative increase in the activity of oxidative enzymes and antioxidant enzymes (Kweki et al., 2018; Ichipi-Ifukor et al., 2019). It can be concluded that the concomitant increase in aldehyde oxidase (an oxidative enzyme) and superoxide dismutase (SOD) (an antioxidant enzyme) from Warri environment is a confirmation of pollution in this area relative to Abraka environment. Pollution 
in Warri has been linked to the presence of both oil and non-oil related industries. The increased level of the heavy metals (a common environmental pollutant) in the soils of Warri relative to Abraka as reported by Egboh et al., (2000) and Adaikpo et al., (2005) may not be unconnected with the presence of the oil and non-oil related industries in Warri. Earlier reports by Asagba (2019) noted that rise in oxidative enzyme activities are adaptable mechanisms for handling stress induced metabolic malignancies in most biological organisms as rise in lipid peroxidation a marker for oxidative stress status are often significantly correlated with increasing oxidative and antioxidant enzyme activities until the rising is lowered because of depletion of the enzyme within the biological system. Results for catalase enzyme activity (Table 1) indicated that the highest was in earthworms from Okere market followed by refinery road and PTI roundabout area while samples from Abraka had the least. Also, significantly increased level of catalase was obtained only in earthworms from refinery road and okere market areas relative to those from Abraka. No significant $(\mathrm{P}>0.01)$ variation was observed in activity of catalase in earthworms from PTI roundabout as compared to Abraka. Thus this study suggests that environmental pollution may not significantly Influence the activity of catalase in earthworms. Ascorbic acid concentrations in earthworms were in the order: Refinery road area $>$ Okere market area $>$ PTI roundabout area $>$ Abraka. Values obtained from Warri study locations are significantly higher than that of Abraka $(p<0.01)$. There was no significant difference in the concentrations of ascorbic acid in samples collected from Okere market area and PTI roundabout arrears all in Warri study locations. However, the concentration of ascorbic acid in earthworm from these areas were significantly lower as compared to those from the Refinery road area. The study therefore is suggestive that ascorbic acid level in earthworms may be responsive to environmental pollution. Results presented in Tables 2-6 shows the probable effects of environmental pollution on the correlation between oxidative stress (LPO) and antioxidant status of earthworms in the various study areas and the combined relationship of all the studied areas. It reveals that there was a significant negative relationship between LPO and SOD activities only in the Refinery road area. Similar trends were observed for the relationship between AO and CAT as well as AO and SOD activities respectively. No significant relationship was observed across the parameters in all other study locations. The combined data however revealed there was a significant negative relationship $(\mathrm{p}<0.01)$ between LPO and AO and a significant positive relationship $(\mathrm{p}<0.01)$ between LPO and SOD, Vit C. There was also a significant positive relationship $(\mathrm{p}<0.01)$ between AO versus CAT, SOD and Vit $\mathrm{C}$, a significant positive relationship $(\mathrm{p}<0.01)$ between Vitamin $\mathrm{C}$ versus SOD and CAT.

Table 2: Correlation Coefficients between Oxidative Stress and Antioxidant Parameters in Refinery Road Area

\begin{tabular}{llllll}
\hline & LPO & AO & CAT & SOD & VITC. \\
\hline LPO & 1 & $-0.412(0.237)$ & $0.063(0.864)$ & $-0.677^{*}(0.030)$ & $0.111(0.760)$ \\
AO & & & $-0.718 *(0.015)$ & $0.661 *(0.037)$ & $-0.166(0.667)$ \\
CAT & & & & $-0.122(0.737)$ & $0.067(0.854)$ \\
SOD & & & & & $0.069(0.850)$
\end{tabular}

Values are expressed as Pearson correlation factor $r$, while values in bracket are significant factors of $p$. Values followed by $*$ are significantly correlated at $p<0.05$ while values followed by ** are significantly correlated at $p<0.01$

Table 3: Correlation Coefficients between Oxidative Stress and Antioxidant Parameters in Okere Market Area

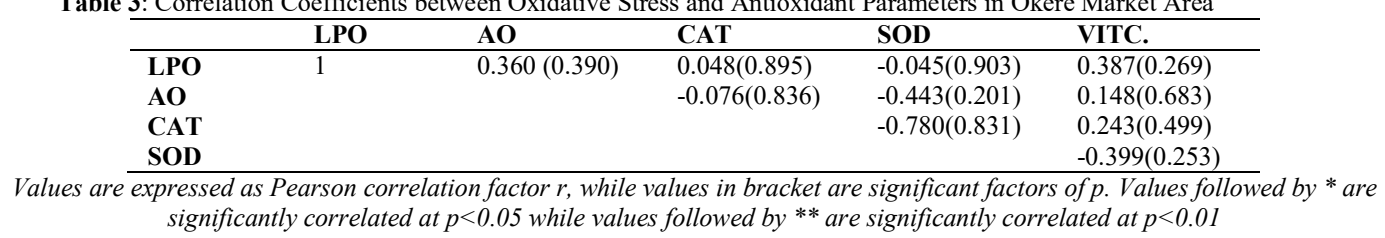

There were similar trends in levels of SOD and lipid peroxidation in the study areas (Refinery Road> PTI $>$ Okere Market $>$ Abraka). This also showed an overall statistical correlation between the two parameters (Table 6) and in Refinery Road (Table 2). This trend observed in the refinery road may not be unconnected with possible discharge of petrochemical effluents from the Warri refinery. This relationship however was insignificant in Okere market area (Table
3), Round about area (Table 4) and Abraka (Table 5). This strongly supports the involvement of superoxide radicals in lipid peroxidation in the earthworms. This is consistent with the views of Treiber et al. (2012) and Nita et al. (2016) that considered superoxide ions important in aging, lipid peroxidation and the per oxidative haemolysis of red blood cells. Patel et al. (2017) also indicated superoxide like other free radicals is toxic and destructive to living cells. 
Table 4: Correlation Coefficients between Oxidative Stress and Antioxidant Parameters in PTI Round about Area

\begin{tabular}{llllll}
\hline & LPO & AO & CAT & SOD & VITC. \\
\hline LPO & 1 & $0.000(1)$ & $-0.385(272)$ & $0.000(1)$ & $0.077(0.833)$ \\
AO & & & $0.046(0.899)$ & $-0.585(0.076)$ & $0.296(0.407$ \\
CAT & & & & $0.585(0.076)$ & $-133(0.714)$ \\
SOD & & & & & $-351(0.320)$
\end{tabular}

Values are expressed as Pearson correlation factor $r$, while values in bracket are significant factors $p$. Values followed by $*$ are significantly correlated at $p<0.05$ while values followed by $* *$ are significantly correlated at $p<0.01$

Table 5: Correlation Coefficients between Oxidative Stress and Antioxidant Parameters in Abraka

\begin{tabular}{llllll}
\hline & LPO & AO & CAT & SOD & VITC. \\
\hline LPO & 1 & $0.164(0.651)$ & $-0.369(0.294)$ & $-0.214(0.553)$ & $0.155(0.668)$ \\
AO & & & $0.423(0.224)$ & $-0.302(0.397)$ & $-0.196(0.587)$ \\
CAT & & & & $0.127(0.726)$ & $0.166(0.647)$ \\
SOD & & & & $-0.237(0.511)$ \\
\hline
\end{tabular}

Values are expressed as Pearson correlation factor $r$, while values in bracket are significant factors $p$. Values followed by * are significantly correlated at $p<0.05$ while values followed by $* *$ are significantly correlated at $p<0.01$

Table 6: Combined Correlation Coefficients between Oxidative Stress and Antioxidant Parameters (All Locations)

\begin{tabular}{llllll}
\hline \multicolumn{1}{r}{ LPO } & AO & CAT & SOD & VITC. \\
\hline LPO & 1 & $-0.719^{* *}(0.000)$ & $0.284(0.076)$ & $0.710^{* *}(0.000)$ & $0.884^{* * *}(0.000)$ \\
AO & & & $-0.486^{* *}(0.001)$ & $-.648^{* *}(0.000)$ & $-0.865^{* *}(0.000)$ \\
CAT & & & $0.109(0.502)$ & $0.424^{* *}(0.006)$ \\
SOD & & & & $0.785^{* *}(0.000)$ \\
\hline
\end{tabular}

Values are expressed as Pearson correlation factor $r$, while values in bracket are significant factors $p$. Values followed by * are significantly correlated at $p<0.05$ while values followed by ** are significantly correlated at $p<0.01$

The trend of ascorbic acid concentration in the study (Refinery road > Okere Market $>$ PTI round about $>$ Abraka) is similar to aldehyde oxidase activity. Although, there is no significant correlation (Table 1) between the antioxidant compound and the oxidative enzyme, it is tempting to speculate from the result of this study that ascorbic acid may be deeply involved in mopping up possible superoxide ions produced by several enzymes as proposed by McCord and Fridovich (1969) for xanthine oxidase and Rajagopulin and Handler (1962) for aldehyde oxidase. However the overall significant correlation between $\mathrm{AO}$ and vitamin $\mathrm{C}$ (Table 6) in all locations may also implicate it in a partial involvement in defense against lipid peroxidation while having a stronger influence over the mopping up of superoxide ions generated from exogenous enzyme activities as well as contributing to the regeneration of other non-haem antioxidants like the glutathione and its attendant cofactor the Nicotinamide adenine dinucleotide phosphate (NADP) (Duart and Lunec 2005; Fadime, 2017). Superoxide dismutase is believed to work in collaboration with the hydrogen peroxide removing enzyme (catalase). Thus a similar trend is expected in the activity of both enzymes. However, this is not the case in the present study (Table 1 and Table 6) as catalase has been shown not to be the major route for the catabolism of hydrogen peroxide as reported by Doroshow et al. (1980), who did not find a corresponding level of activity in SOD and catalase. Besides, another possible explanation to this observation may be linked to an earlier report that vitamin $\mathrm{C}$ contributes to the inhibition of the antioxidant enzyme catalase thus limiting its ability to mop up the hydrogen peroxide released in a stressed environment (Cadenas, et al., 1994; Klingelhoeffer et al., 2004).

Conclusion: The present study indicates that the levels of aldehyde oxidase, superoxide dismutase, ascorbic acid and lipid peroxidation in earthworms in the Warri environment are higher than those observed in Abraka a less industrial city. Thus, increased levels of aldehyde oxidase, superoxide dismutase, ascorbic acid concentration and lipid peroxidation in earthworms may be in response to increased pollution of the Warri environment and could be used to monitor environmental pollution.

\section{REFERENCES}

ACHUBA, FI (2018). Protective influence of Elaesis guineensis leaf in diet on petroleum-mediated kidney damage in rats. Nig J Pharm Appl Sci Res. 7(2):33-38.

ACHUBA, FI (2019). Protective Role of Elaesis guineensis Leaves against Crude Oil Tainted Diet-induced Hematotoxicity in Wistar Rats. Iran J. Toxicol.; 13(4):1-4

ACHUBA, FI (2008). African land snail Achatina marginatus, as bioindicator of environmental pollution. North-Western J. Zoo. 4, (1):1-5 
ACHUBA, FI; PERETIEMO-CLARKE; BO; Ebokaiwe, P. (2005): Pollution induced oxidative stress in African catfish (Clarias heterobranchus). Euro. J. Sci. Res. 8 (2): 62-73.

ADAIKPOH, EO; KAZIER, AN; OSAKWE, SA (2005). Distribution of Heavy metals in subsurface soils in Abraka and environs, Southwestern Nigeria. Afr. Scientist, 6:29-33

AGHOGHOVWIA, OA (2011). Physico-chemical characteristics of Warri River in the Niger Delta region of Nigeria. J. Environ. Iss. Agric. Develop. Countries, 3(2), 40-46.

AKPOBORIE, IA (1996). Pollution from Oil in Delta State. In Environmental Issues in Delta State (pp. 49-59). Chevirol Resources Ltd., Ibadan.

AREMU, DA; OLAWUYI, JF; MESHITSUKA, S; SRIDHAR, MK; OLUWANDE, PA (2002) Heavy metal analysis of groundwater from Warri, Nigeria, Intl J. Environ. Health Res. 12:3, 261267

ARIMORO, FO; IWEGBUE, CMA; OSIOBE, O (2008). Effects of industrial waste water on the physical and chemical characteristics of a tropical coastal river. Res. J. Environ. Sci., 2: 209-220.

ASAGBA, SO (2019) Cadmium in our food and drinking water; should we be worried? $70^{\text {th }}$ in the series of inaugural lectures of the Delta State University, Abraka. $14^{\text {th }}$ February, Delsu Press.

ASAGBA, SO (2010). Alteration in the activity of oxidative enzymes in the tissues of male Wistar Albino rats exposed to cadmium. Int. J. Occupt. Med. Environ. Health. 23(1): 55 - 62.

BABATOLA, O; URIRI, A (2013). Assessment of Maternal Health Intervention Programme of Delta State, Nigeria:Application of the U.N Process Indicators. J. Pub. Policy Admin. Res. 3(9), 6271.

CADENAS, S; ROJAS, C; PÉREZ-CAMPO, R; LÓPEZ-TORRES M; BARJA, G (1994) Effect of Dietary Vitamin $C$ and Catalase Inhibition on Antioxidants and Molecular Markers of Oxidative Damage in Guinea Pigs, Free Rad. Res. 21:(2):109-118

COHEN G, DEMBIEC D, MARCUS J (1970). Measurement of catalase activity in tissue extracts. Anal Biochem. 34:30-38.
DAWOOD, M; WAHID, A; MUKHTAR, S; HASHMI, MZ; MALIK, Z (2017). Use of Earthworms in Biomonitoring of soil xenobiotics. In: Xenobiotics in the Soil Environment: Monitoring, Toxicity and Mangement. Hashmi, M.Z., Kumar, V.and Varma, A. (eds). Springer International Publishing AG.

DEMUYNCK, S; GRUMIAUX, F; MOTTIER, V; SCHIKORSKI, D; LEMIERE, S; LEPRETRE, A. Metallothionein response following cadmium exposure in the oligochaete Eisenia fetida Comp Biochem Physiol C Toxicol Pharmacol. 144(1):34-46.

DIMPAL, V. (2012). Urbanization and Solid Waste Management in India: Present Practices and Future Challenges. Procedia-Social Behav. Sci. $37: 437-447$

DOROSHOW, JH; LOCKER, JY; MEYERS, CE (1980). Enzymatic defenses of the mouse heart against reactive oxygen metabolites: alterations produced by doxorubicin. J. Clin. Invest. 65:128135

DUARTE, TL; LUNEC, J (2005). Review: When is an antioxidant not an antioxidant? A review of novel actions and reactions of vitamin C. Free Rad. Res. 39(7):671-686

DURÁN, CES; MESSINA， S (2019). Urban Management Model: Municipal Solid Waste for City Sustainability. In Saleh, H. (Eds). Municipal Solid Waste Management. IntechOpen. DOI: 10.5772/intechopen. 82839

EDEGBENE, AO; ARIMORO, FO (2012). Ecological Status of Owan River, Southern Nigeria Using Aquatic Insects As Bio-indicators. J. Aquatic Sci. 27(2):99-111

EGBOGE, ABM (1995): Water pollution in Nigeria. Bodiversity and chemistry of Warri River. Ben Miller Books. Nig Ltd Warri

EGBOH, SHO; NWAJEI, GE; ADAIKPOH, EO (2000). Selected heavy metals concentration in sediments from major roadside Gutters in Warri, Delta State Nigeria. Nig. J. Sci. Environ., 2:105111

EMOYAN, OO; AKPORHONOR, EE; AKPOBORIE, IA (2008). Environmental Risk Assessment of River Ijana, Ekpan, Delta State. Chem. Spec. Bioavailability, 20(1), 23-32 
ERYILMAZ, FP (2017). Vitamin C: An Antioxidant Agent.

http://dx.doi.org/10.5772/intechopen.69660

EZEDOM, T; ASAGBA, SO (2016). Effect of a controlled food-chain mediated exposure to cadmium and arsenic on oxidative enzymes in the tissues of rats. Toxicol Rep. 3:708-715.

GHANEM, SK (2018). The relationship between population and the environment and its impact on sustainable development in Egypt using a multiequation model. Environ Dev Sustain. 20, 305342.

HALL, ED; BRAUGHLER, JM (1989). Free Radical. Biol. Med., 6:303-313

ICHIPI-IFUKOR, PC; ASAGBA, SO; KWEKI, GR; NWOSE, C. (2019). Attenuation of Oxidative Enzymes Induction in Palm Oil Fractions Pretreated Cadmium Intoxicated Rats. Trop. J. Natural Prod. Res. 3(4):107-112.

IGIRI, BE; OKODUWA, S; IDOKO, G.O; AKABUOGU, EP; ADEYI, AO; EJIOGU, IK. (2018). Toxicity and Bioremediation of Heavy Metals Contaminated Ecosystem from Tannery Wastewater: A Review. J. Toxicol., 2018:2568038.

ISAMAH, GK; ASAGBA, SO (2004). A comparative study on the archives of xanthine oxidase and aldehyde oxidase in different fish species from two rivers in the Western Niger-Delta. Environ. Monit. Assess. 91:293-300

JOHNS, DG (1967) Human Liver Aldehyde Oxiidase: Differential Inhibition of. Oxidation of Charged and Uncharged Substrates. J. Clin. Invest. 46, 1492-1505. 27

KADAM, RS; IYER, KR (2008). Isolation of Liver Aldehyde Oxidase Containing Fractions from Different Animals and Determination of Kinetic Parameters for Benzaldehyde. Ind J Pharm Sci. 70(1):85-88.

KLINGELHOEFFER, C; KÄMMERER, U; KOOSPAL, M; MÜHLING, B; SCHNEIDER, M; KAPP, M ... OTTO, C. (2012). Natural resistance to ascorbic acid induced oxidative stress is mainly mediated by catalase activity in human cancer cells and catalase-silencing sensitizes to oxidative stress. BMC Compl. Altern. Med., 12:61.
KLOTZ, L; STEINBRENNE, H. (2017). Cellular adaptation to xenobiotics: Interplay between xenosensors, reactive oxygen species and FOXO transcription factors Redox Bio. 13:646-654

KWEKI, GR; ICHIPI-IFUKOR, PC; ASAGBA, SO (2018). High caffeine-containing Energy drinkInduced Metabolic stress in Rats. Sok. J. Med. Lab. Sci. 3(3):86-93

MCCORD, YM; FRIDOVICH, I (1969). Superoxide dismutase; an enzyme function for erythrocuperin (Haemocuprein). J. Biol. Chem., 244:6049-6055.

NAHMANI, J; HODSON ME; BLACK S (2007b) Effects of metals on life-cycle parameters of the earthworm Eisenia fetida exposed to fieldcontaminated, metal-polluted soils. Environ. Pollut. 149:44-58.

NAHMANI, J; HODSON ME; BLACK SA (2007a) review of studies performed to assess metal uptake by earthworms. Environ. Pollut. 145:402424.

NDUKA, JK; ORISAKWE, OE (2009). Effect of Effluents from Warri Refinery Petrochemical Company WRPC on Water and Soil Qualities of "Contiguous Host" and "Impacted on Communities" of Delta State, Nigeria. The Open Environ. Pollut. Toxicol. J. 1:11-17.

NITA, M; GRZYBOWSKI, A (2016). The Role of the Reactive Oxygen Species and Oxidative Stress in the Pathomechanism of the Age-Related Ocular Diseases and Other Pathologies of the Anterior and Posterior Eye Segments in Adults. Oxidat. Med. Cellu. Longe. 2016:3164734.

OBAFEMI, AA; ELUDOYIN, OS; AKINBOSOLA, BM (2012). Public Perception of Environmental Pollution in Warri, Nig. J. Appl. Sci. Environ. Managt. 16(3):233-240

OCHERI, MI; ODOMA, LA; UMAR, ND (2014). Groundwater Quality in Nigerian Urban Areas: A Review. Glob. J. Sci. Front. Res: H Environ. Earth Sci. 14(3):35-45

OGAMBA, EN; IZAH SC; OMONIBO, E (2016). Bioaccumulation of hydrocarbon, heavy metals and minerals in Tympanotonus fuscatus from coastal region of Bayelsa State, Nigeria. Int. J. Hydrology Res., 1: $1-7$ 
OGWULEKA, TC (2009). Municipal Solid Waste Characteristics and Management in Nigeria. Iran J. Environ. Health. 6(3): 173-180.

OHIMAIN, E.I (2012). Environmental Impacts of oil mining activities in the Niger Delta Mangrove Ecosystem. Proceedings of the 8th International Congress on Mine Water \& the Environment, Johannesburg, South Africa. Pp.503-517

OLALEKAN, A; GORDON, M. (2011) The Niger Delta wetlands: threats to ecosystem services, their importance to dependent communities and possible management measures, Intl. J. Biodiver. Sci. Eco. Serv. Managt. 7(1):50-68

ONI, AA; HASSAN, AT (2013). Acute and SubLethal Toxic Effects of a Contaminated Dumpsite Soil to the Earthworm, Eisenia fetida (Savigny, 1826). J. Scientific Res. Rep. 2(2): 544-558

OSIOMA, E; HAMILTON-AMACHREE, A. (2018). Heavy metal accumulation and biomarker responses in the earthworm (Lumbricus terrestris) collected from Kolo Creek, Bayelsa State, Nigeria. FUW Trends Sci. Technol. J. 4(2):319323

OTMANI DEL BARRIO, M; SIMARD, F; CAPRARA, A (2018). Supporting and strengthening research on urban health interventions for the prevention and control of vector-borne and other infectious diseases of poverty: scoping reviews and research gap analysis. Infect. Dis. Pov. 7(1):94. Doi: 10.1186/s40249-018-0462-z

PATEL, R; RINKER, L; PENG, J; CHILIAN, WM (2017). Reactive Oxygen Species: The Good and the Bad, Reactive Oxygen Species (ROS) in Filip and Albu, (Eds.) Living Cells, IntechOpen, DOI: 10.5772/intechopen.71547. Available from: https://www.intechopen.com/books/reactiveoxygen-species-ros-in-living-cells/reactiveoxygen-species-the-good-and-the-bad
PLUMBER, DF (1978). An introduction to practical Biochemistry. Mcgraw Hill Book Company, London.

RAJAGOPALAN, KV; HANDLER, P (1962). Oxidation of phenazine methosulfate by hepatic aldehyde oxidase. Biochem. Biophys. Res. Commun. 19; 8:43-7

SHARMA, P; JHA, AB; DUBEY, RS; PESSARAKLI, M (2012). Reactive Oxygen Species, Oxidative Damage, and Antioxidative Defense Mechanism in Plants under Stressful Conditions. J. Bot., 2012:217037,2

SHERBININ, A; CARR, D; CASSELS, S; JIANG, L, (2007). Population and environment. Annu Rev Environ Resour. 32: 345-373.

SPURGEON DJ; HOPKIN SP. (1996) Effects of metal-contaminated soils on the growth, sexual development, and early cocoon production of the earthworm Eisenia fetida, with particular reference to zinc. Ecotoxicol. Environ. Saf. 35:8695.

TREIBER, N; MAITY, P; SINGH, K; FERCHIU, F; WLASCHEK, M; SCHARFFETTERKOCHANEK, K. (2012). The role of manganese superoxide dismutase in skin aging. Dermatoendocrinol., 4(3), 232-235.

VANDECASTEELE, B; SAMYN, J; QUATAERT, P; MUYS, B; TACK, FMG (2004). Earthworm biomass as additional information for risk assessment of heavy metals biomagnification: a case study for dredged sediment-derived soils and polluted floodplain soils. Environ. Pollut. 129(3):363-375 